\title{
Balkanologie
}

Balkanologie Revue d'études pluridisciplinaires

Vol. IV, $n^{\circ} 1 \mid 2000$

Volume IV Numéro 1

\section{Notices bibliographiques balkaniques}

\section{(2) OpenEdition}

12 Journals

Édition électronique

URL : http://journals.openedition.org/balkanologie/2206

DOI : 10.4000/balkanologie.2206

ISSN : 1965-0582

Éditeur

Association française d'études sur les Balkans (Afebalk)

Édition imprimée

Date de publication : 1 septembre 2000

ISSN : 1279-7952

Référence électronique

"Notices bibliographiques balkaniques », Balkanologie [En ligne], Vol. IV, $n^{\circ} 1$ | 2000, mis en ligne le 30 juillet 2010, consulté le 17 décembre 2020. URL : http://journals.openedition.org/balkanologie/2206 ; DOI : https://doi.org/10.4000/balkanologie.2206

Ce document a été généré automatiquement le 17 décembre 2020.

(c) Tous droits réservés 


\section{Notices bibliographiques balkaniques}

\section{Bosnie-Herzégovine}

DIZDAREVIć (RAIF), Od smrti Tita do smrti Jugoslavije : svjedoćenja (De la mort de Tito à la mort de la Yougoslavie : témoignages), Sarajevo : Oko, 1999, 459 p.

\section{Bulgarie}

ДАйнов (Евгений), Преходът, 1989-1999 : вместо история (La transition, 1989-1999 : en guise d'histoire), София: Планета 3, 1999, 255 р.

КҮмАнов (Милен), НиколовА (ТАня), ПолитичеСКи партии, организации и движения в България и техните лидери 1879-1999 : кратък справочник (Les partis, les organisations, les mouvements politiques et leurs leaders en Bulgarie, 1879-1999), София : Ариадна, 1999, 272 р.

МАнчев .(КРъстьо), История на балканските народи, XIX-XX в. (Histoire des peuples balkaniques, XIXѐme-XXème siècles), София : Марин Дринов, 1999, 330 p.

мАнчев .(кРъстьо), Националният въпрос на Балканите (La question nationale dans les Balkans), София : Марин Дринов, 1999, 359 р.

нАзърска (ЖоржетА), Българската държава и нейните малцинства, 1879-1885 (L'État bulgare et ses minorités, 1879-1885), София : Лик, 1999, 271 р.

ЧАвдАРовА (мАРия), Балкански страни : политика, икономика, международни връзки, (Les pays balkaniques : politique, économie, relations internationales), София : Парадигма, 1999, 126 p.

\section{Croatie}

Letica (sLAVen), Političko pleme 2 (Tribu politique 2), Zagreb : Jesenski i Turk, 1999, 526 p.

2 Portraits des différents acteurs politiques croates, typologie des courants et des valeurs politiques en Croatie.

MAgaš (BRANKA), ZANıć (IVo), Rat u Hrvatskoj i Bosni i Hercegovini 1991-1995. (La guerre en Croatie et Bosnie-Herzégovine, 1991-1995), Zagreb : Jesenski i Turk / Sarajevo : Dani, 1999, 399 p.

томас (zDravko), Zločin bez kazne (Crime sans châtiment), Zagreb : Z. Tomac ; Trst : Matrix Croatica, 1999, $480 \mathrm{p}$. 
3 Professeur de science politique, homme politique, Z. Tomac relate et analyse les événements de la dernière décennie: guerre en Croatie et Bosnie-Herzégovine, nationalisme serbe, etc.

\section{Serbie (R.F. Yougoslavie)}

GOATI (VLADIMIR), Izbori u SRJ od 1990. do 1998. : volja građana ili izborna manipulacija (Elections en RFY de 1990 à 1998 : volonté des citoyens ou manipulation électorale), Beograd : CESID, 1999, 303 p.

RISTIĆ (SNEŽANA), Leposavić (RADONJA), eds., Sta ste uradili u ratu : glasovi iz crne rupe (Qu'avezvous fait pendant la guerre : voix du trou noir), Beograd : K.V.S., 1999, 429 p.

Entretiens avec 27 intellectuels serbes engagés contre le nationalisme et en faveur des changements démocratiques, signataires d'un appel à l'arrêt de la violence pendant la guerre le 22 avril 1999. Multiples réflexions sur la montée du nationalisme, la nature du régime de Slobodan Milošević, la guerre au Kosovo, l'intervention de l'OTAN contre la Yougoslavie.

JOVANOVIĆ (MIROSLAV), KASER (KARL), NAUMOVIĆ (SLOBODAN), eds., Between the archives and the field : a dialogue on historical anthropology of the Balkans, Belgrade : Udruženje za društvenu istoriju / Graz : Institut für Gesichte der Universität Graz, Abteilung Südosteuropäische Gesichte, 1999, 276 p. (Zur Kunde Südosteuropas - Band II/27 ; Udruženje za društvenu istoriju, Teorija 1).

EKMEс̌ı́́ (MiLORAD), Срби на историјском раскршћу (Les Serbes, au carrefour de l'Histoire), Beograd : Srpska književna zadruga, 1999, 482 p., (Srpska književna zadruga ; kolo 92, knj. 612).

MARKović (PREDRAg), Minić (JELICA), eds., Jugoistočna Evropa 2000 : pogled iz Srbije (L'Europe du sud-est en 2000 : regard de Serbie), Beograd : Stubovi kulture, 1999, 207 p. 